\title{
A geological and geophysical context for the Wenchuan earthquake of 12 May 2008, Sichuan, People's Republic of China
}

B.C. Burchfiel, L.H. Royden, R.D. van der Hilst, B.H. Hager, Dept. of Earth, Atmospheric, and Planetary Sciences, Massachusetts Institute of Technology, Cambridge, Massachusetts 02139, USA; Z. Chen, Chengdu Institute of Geology and Mineral Resources, Chengdu, People's Republic of China; R.W. King, C. Li, J. Lü, H. Yao, Dept. of Earth, Atmospheric, and Planetary Sciences, Massachusetts Institute of Technology, Cambridge, Massachusetts 02139, USA; and E. Kirby, Dept. of Geosciences, Pennsylvania State University, University Park, Pennsylvania 16802, USA;

\section{ABSTRACT}

On 12 May 2008, a magnitude 7.9 earthquake ruptured the Longmen Shan margin of the eastern Tibetan plateau. This event occurred within the context of long-term uplift and eastward enlargement of the plateau. The area has numerous geological features not typical of active convergent mountain belts, including the presence of a steep mountain front ( $>4 \mathrm{~km}$ relief) but an absence of large-magnitude low-angle thrust faults; young high topography (post ca. $15 \mathrm{Ma}$ ) and thickened crust but low global positioning system (GPS) shortening rates $(<3 \mathrm{~mm} / \mathrm{yr})$; and no coeval foreland subsidence. In our interpretation, crustal thickening beneath the eastern Tibetan plateau occurred without large-scale shortening of the upper crust but instead is caused by ductile thickening of the deep crust in a weak (lowviscosity) layer. Late Cenozoic shortening across the Longmen Shan could be as little as $10-20 \mathrm{~km}$, with folding and faulting mainly accommodating differential surface uplift between the plateau and the Sichuan Basin. The earthquake of 12 May probably reflects long-term uplift, with slow convergence and right-slip, of the eastern plateau relative to the
Sichuan Basin. GPS-determined rates in the vicinity of the 12 May event suggest an average recurrence interval of $\sim 2,000-10,000 \mathrm{yr}$.

\section{INTRODUCTION}

On 12 May 2008, a magnitude 7.9 earthquake occurred beneath the steep eastern margin of the Tibetan plateau in Sichuan, China (Fig. 1). Rupture occurred over a length of $\sim 270 \mathrm{~km}$ along a north-northeast-striking, west-dipping to steep fault beneath and parallel to the northeast-striking Longmen Shan thrust belt (as reported by the U.S. Geological Survey, National Earthquake Information Center, 2008). Coseismic slip, estimated at up to $\sim 10 \mathrm{~m}$, consists of thrust- and right-slip components, with initial rupture occurring at $\sim 10-20 \mathrm{~km}$ depth (Ji, 2008). The rupture plane and the aftershock sequence extend northeast of the Longmen Shan range, and the faulting geometry along the rupture appears to be complex. Reverse and right-slip components are of comparable magnitude along the southwestern portion of the rupture, but right-slip dominates the northeastern portion of the rupture.

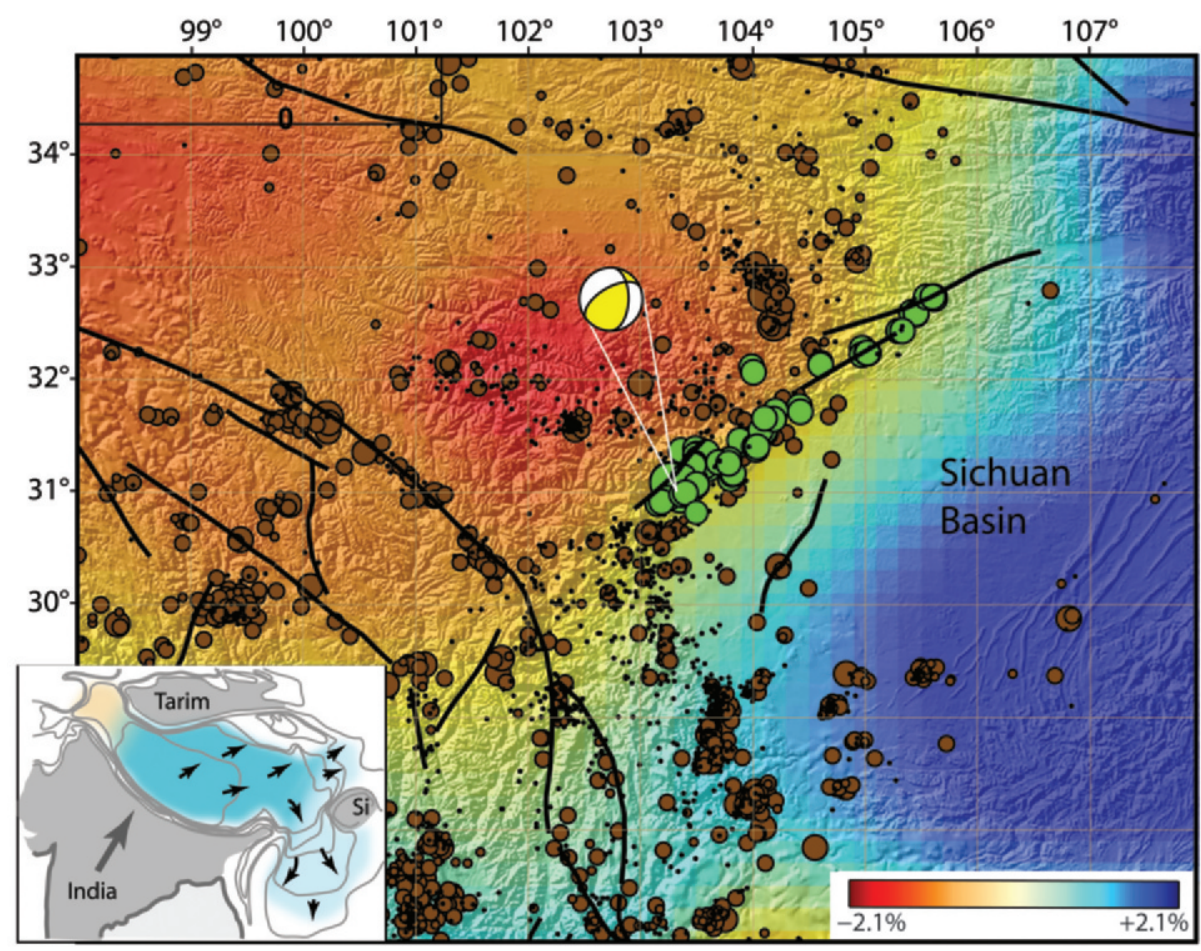

Figure 1. Epicenters of the 12 May 2008 Wenchuan earthquake and aftershocks (green circles), with focal mechanism for the main event as reported by the U.S. Geological Survey's National Earthquake Information Center (2008). Events are superimposed on map of lateral variation in P-wave speed at $100 \mathrm{~km}$ depth relative to a laterally homogeneous reference earth model (Li et al., 2006, 2008). Brown dots-regional seismicity (body wave magnitude $m_{b}>3$, symbol size scaled with magnitude, time interval 1964-2007 from Engdahl et al., 1998, EHB catalog). Inset shows regional-scale setting of Tibet with approximate directions of surface motion relative to eastern China. Si-Sichuan Basin. 
Several faults are likely candidates for rupture, including the northeast-trending Beichuan and Wenchuan faults. It is possible that coseismic displacement along the southwestern and northeastern segments of the fault break occurred on different, but contiguous, faults that broke during the same event. To date, surface ruptures have not been well documented, and details of the slip distribution and fault geometry remain unclear. Nevertheless, geological, geodetic, and geophysical data allow us to place this major seismic event within the context of ongoing deformation along the eastern margin of the Tibetan plateau.

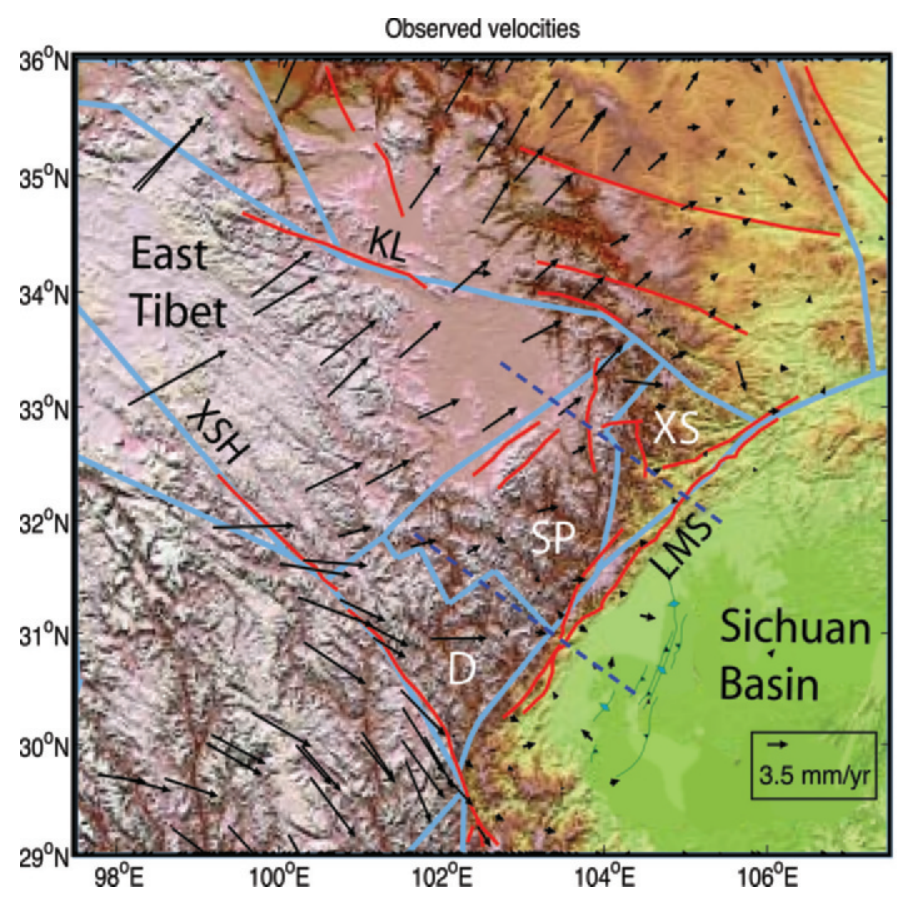

Figure 2. Selected active faults (red) and block boundaries used for GPS modeling (light blue). Blocks: D—Danba; SP-Songpan; XS—Xue Shan. Fault zones: XSH—Xianshuihe fault; $\mathrm{KL}$-Kun Lun fault; LMS—Longmen Shan. Dashed purple lines-profile locations for Figure 3. Black arrowsobserved GPS velocities relative to the South China block. Standard errors for north and east velocity components are $1-1.5 \mathrm{~mm} / \mathrm{yr}$.

\section{OVERVIEW}

In the vicinity of the 12 May 2008 earthquake, hereafter referred to as the Wenchuan earthquake, the eastern margin of the Tibetan plateau rises steeply westward from $500 \mathrm{~m}$ to $>4000$ m elevation (Figs. 2 and 3). Mountain peaks within the Longmen Shan reach elevations higher than $6000 \mathrm{~m}$. The eastern plateau margin formed by the Longmen Shan coincides with steep gradients in crustal thickness (from $60-65 \mathrm{~km}$ in the west to $40 \mathrm{~km}$ in the east; Xu et al., 2007; Yao et al., 2008) and seismic wave speed (from slow in the west to high in the east; Fig. 1)

Late Cenozoic deformation and crustal thickening in the Longmen Shan are related to eastward enlargement of the high Tibetan plateau. Global positioning system (GPS) data and earthquake focal solutions show eastward movement of upper crust away from the central Tibetan plateau and into the eastern plateau region at rates of $\sim 15-20 \mathrm{~mm} / \mathrm{yr}$ (Fig. 2). Eastward, crust located south of the left-slip Xianshuihe fault moves southeast relative to the Sichuan Basin, while crust north of the fault moves northeast.

Little of the northeastward crustal motion measured in the eastern plateau reaches the Longmen Shan (Zhou et al., 2007), but GPS sites west of and within the Longmen Shan are not sufficiently dense to determine where the deformation is localized. Mapping of important active fault zones provides some constraints, but the locations of some active deformation zones are still speculative. Elastic block modeling of GPS data indicates $<\sim 3 \mathrm{~mm} / \mathrm{yr}$ convergence and $\sim 1 \mathrm{~mm} / \mathrm{yr}$ of right-slip along the Longmen Shan boundary. Northward, convergence is taken up across at least two zones. Our block model yields $\sim 3 \mathrm{~mm} / \mathrm{yr}$ of convergence across the Min Shan and $\sim 1 \mathrm{~mm} / \mathrm{yr}$ across the northern Longmen Shan; the latter also accommodates $\sim 1 \mathrm{~mm} / \mathrm{yr}$ of right-slip.

\section{GEOLOGY OF THE WENCHUAN EARTHQUAKE REGION}

\section{Longmen Shan}

The Cenozoic deformation of the Longmen Shan, including the active faulting related to the Wenchuan earthquake, is superimposed on a preexisting Mesozoic orogen. This older

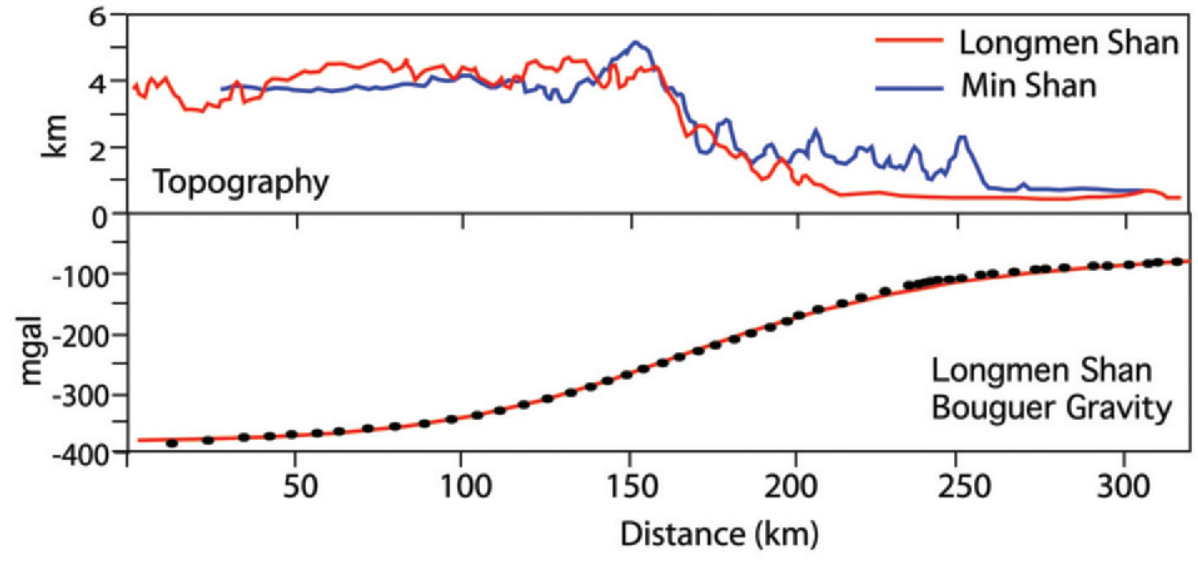

Figure 3. Topography profiles across the Min Shan and Longmen Shan and observed (dots) and computed (line) Bouguer gravity anomalies for Airy compensation of the Longmen Shan for a density contrast between crustal root and mantle of $400 \mathrm{~kg} / \mathrm{m}^{3}$. Gravity data from Jiang and $\mathrm{Yu}(2005)$ 


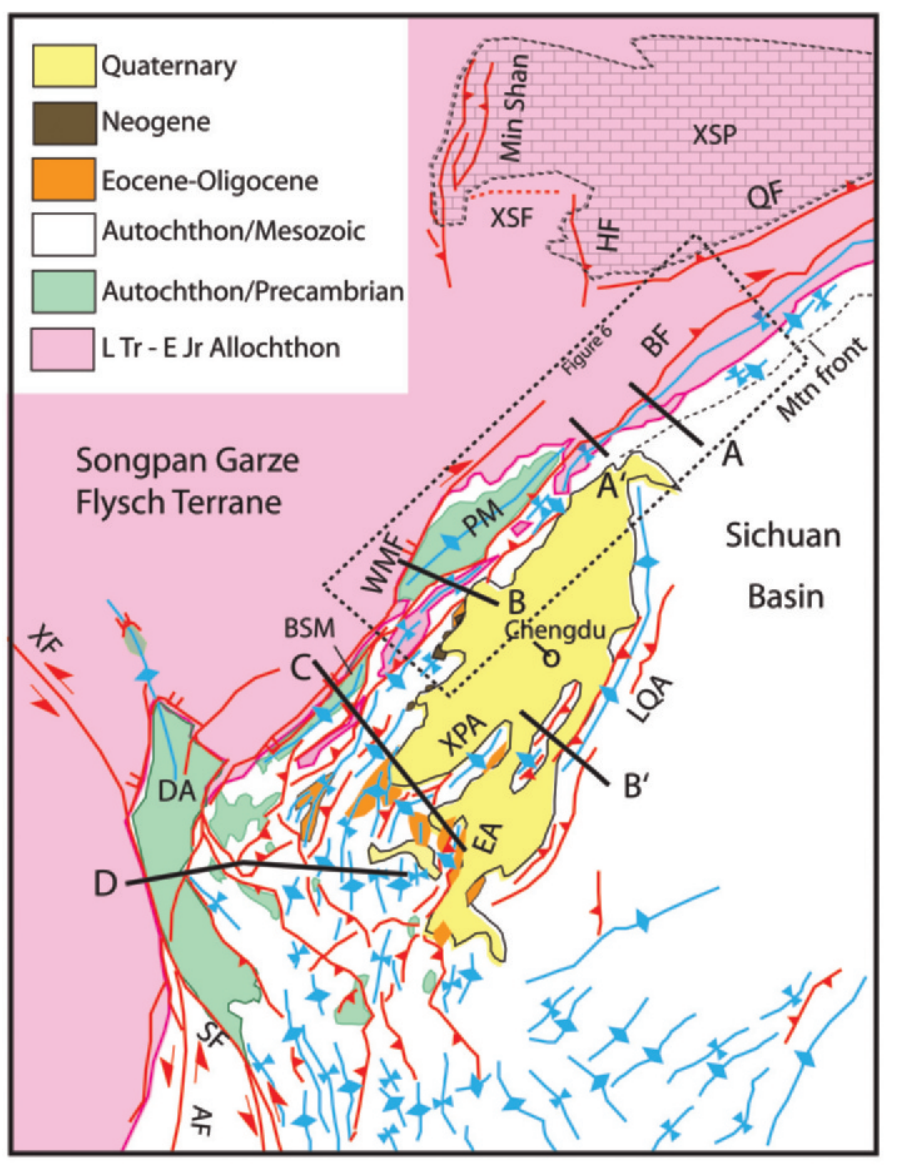

Figure 4. General tectonic map of the Longmen Shan region. AF-Anninghe fault; BF-Beichuan fault; HF-Huya fault; QF-Qingchuan fault; SF-Shimian fault; WMF-Wenchuan-Maowen fault; XF-Xianshuihe fault; XSF_Xue Shan Fault; BSM—Baoshan massif; PM—Pengguan massif; XSP-Xue Shan plateau (pattern/dashed outline); DA-Danba antiform; EA-Emei anticline; LQA-Longquan anticline; XPA—Xiong Po anticline. Red -major Cenozoic faults; purple-Upper Triassic-Lower Jurassic thrusts; blue-Cenozoic folds. On Cenozoic faults: barbs-thrust faults; ticked lines - normal faults; arrows - strike-slip. Figure 5 cross sections and location of map in Figure 6 also indicated.

deformation provides the starting geometry for later Cenozoic deformation (see Burchfiel et al., 1995).

Mesozoic deformation in the Longmen Shan took place in Late Triassic and Jurassic time, when two distinct structural sequences were deformed and juxtaposed by thrust faulting (Figs. 4 and 5). The autochthonous lower sequence consists mainly of late Precambrian basement rocks overlain by an incomplete section of latest Proterozoic to Middle Triassic shallow-water sedimentary rocks and Upper Triassic-Jurassic clastic rocks that appear to be foredeep basin deposits and grade eastward into finer-grained strata in the Sichuan Basin.

The eastern part of the upper structural sequence has a Precambrian crystalline basement overlain by a thick succession of latest Proterozoic to Lower Triassic shallow-water, highly metamorphosed sedimentary rocks. The western part of the upper sequence consists of up to $10 \mathrm{~km}$ of Middle to Upper Triassic flysch, which extends across a broad area of eastern Tibet as the Songpan Garze flysch. This upper structural

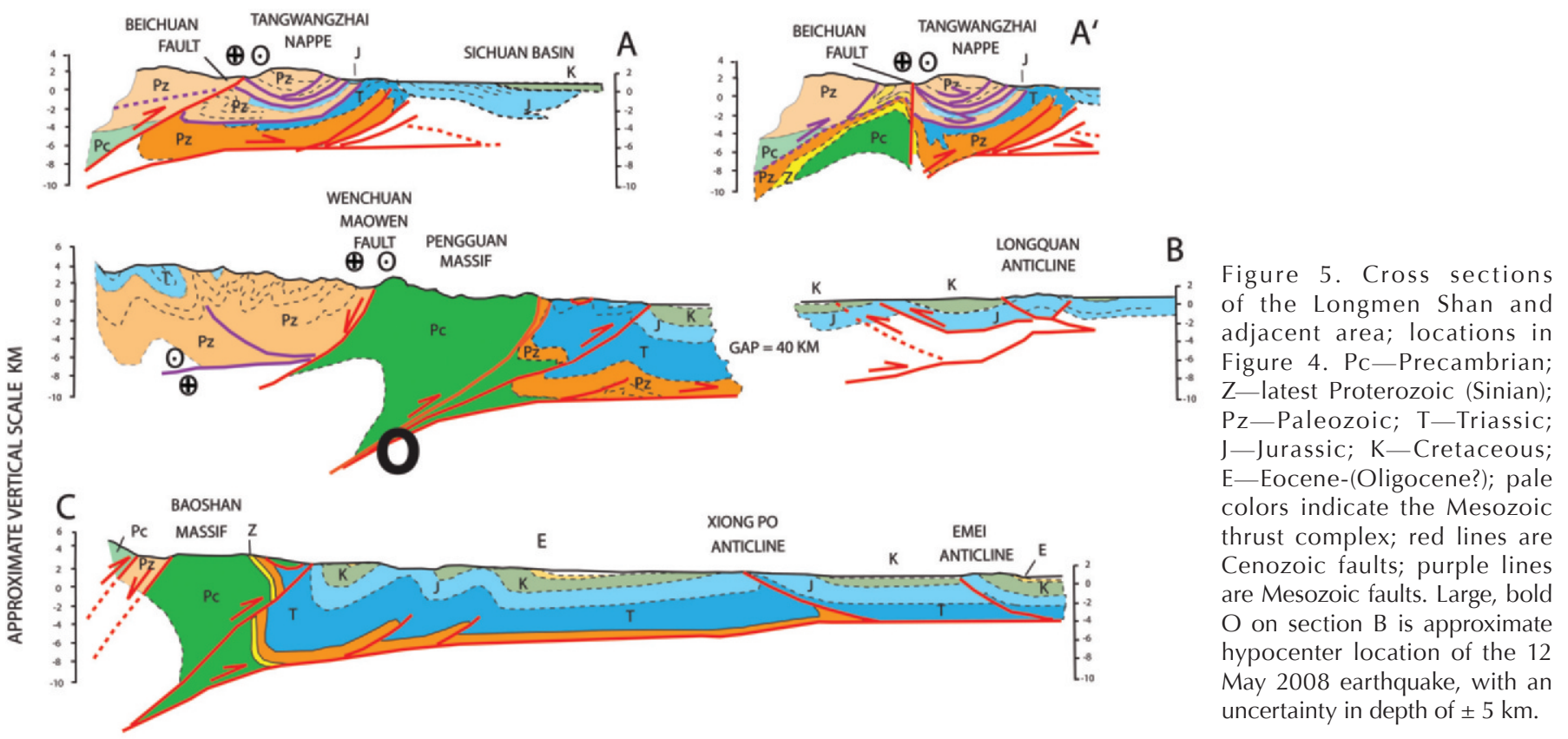

D XIANSHUIHE DADU RIVER

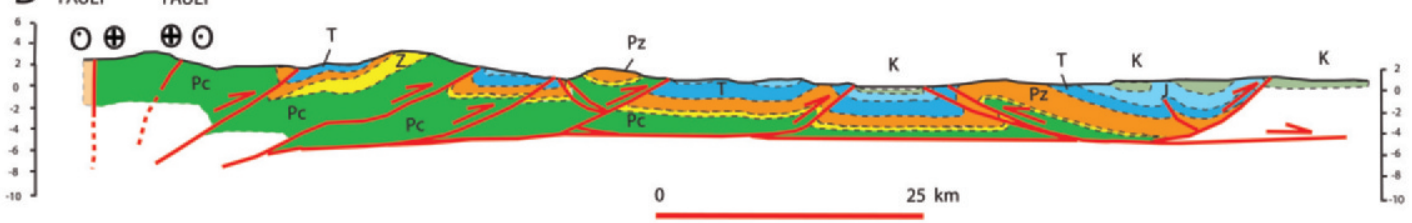




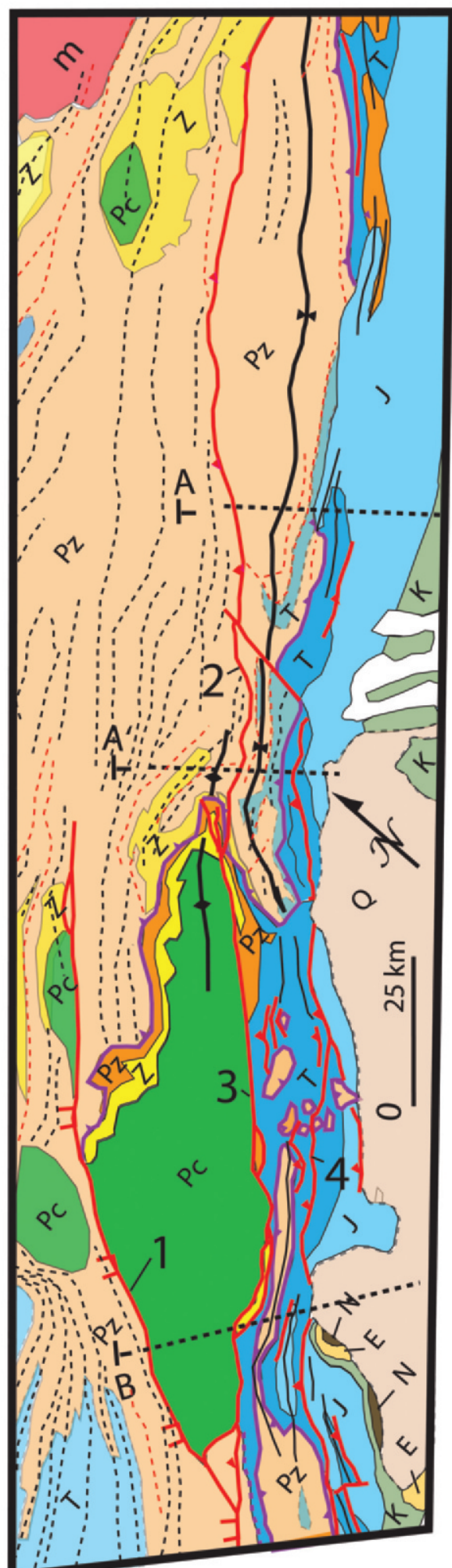

Figure 6. Detailed geologic map of the Longmen Shan. Pale colors indicate the Mesozoic thrust complex. Locations of some cross sections shown. Pc-Precambrian; Z-latest Proterozoic (Sinian); Pz-Paleozoic; T-Triassic; J-Jurassic; K-Cretaceous; E-Eocene-(Oligocene?); $\mathrm{m}$-metamorphic rocks of unknown protolith; $\mathrm{N}$-Neogene. Solid red lines are major Cenozoic faults; thin black lines are Cenozoic fold axes; purple lines are Mesozoic faults. Thin dashed black lines indicate fold axes in the Mesozoic thrust complex, and thin red lines are faults in the Mesozoic thrust complex, both presumed to be of Mesozoic age. Heavy black lines show a synform and an antiform that fold the Mesozoic thrust complex and are presumed to be Cenozoic. Major faults: 1-Wenchuan-Maowen fault; 2-Beichuan fault; 3-Yingxiu-Beichuan fault; 4-Guanxian-Anxian fault.

sequence was imbricated and emplaced eastward over the lower structural sequence in Late Triassic to Middle Jurassic time. Transitional units between the two structural sequences are generally not found.

Thrust sheets override the older foredeep deposits, and thrust contacts are sealed in places by Middle Jurassic strata, constraining the end of thrusting to the pre-Middle Jurassic. The foredeep deposits continue into the Late Cretaceous, but large post-Middle Jurassic, pre-Oligocene structures have not been identified.

The Mesozoic thrust complex and its underlying autochthon were refolded and thrust eastward in Cenozoic time. Cenozoic folding of the Precambrian basement is well expressed in the Baoshan and Pengguan massifs (Figs. 4 and 5). Along the southwestern margin of the Sichuan Basin, Eocene and probable Oligocene red beds are deformed by northeast-trending folds and thrust faults that merge northward into the Longmen Shan. These rocks constrain the Cenozoic deformation in this area to

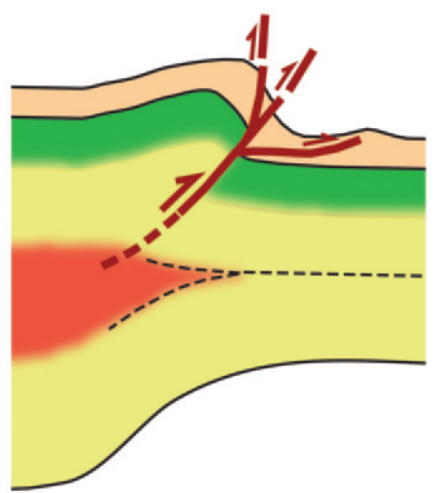

Figure 7. Left: Idealization of cross section $\mathrm{A}^{\prime}$ as a fault propagation fold, with minor slip on a subhorizontal fault extending eastward below the western Sichuan basin. Possible faults through the syncline that might propagate to the surface are indicated by red dashed lines. Pc-Precambrian crystalline basement; Pz_Paleozoic strata; ET—Early Triassic strata; LT-Jr—Late Triassic foredeep strata. Right: Sketch showing a highly simplified geometry that might relate upper crustal faulting and folding in the Longmen Shan to thickening of a weak, low-viscosity layer (red shading) in the deep crust beneath eastern Tibet. (Sketch is not to scale.) Thin dashed line in the mid-crust illustrates the possible disruption of the flexurally strong portion of the Sichuan Basin lithosphere.

have been initiated in the late or postOligocene. Uncommon, presumed Neogene, conglomerates in the Longmen Shan (Fig. 6) are less folded than the underlying Early Cenozoic rocks.

Cenozoic thrust faults in the Longmen Shan do not have large displacements; folded strata can be matched across the faults. At the north end of the Pengguan massif, the plunging fold that involves basement also folds the overlying Mesozoic thrust complex, and at the north end of both basement massifs, sedimentary rocks on the west side of the massifs have a gentle west dip where the basement plunges beneath them. The largescale Cenozoic structure of the Longmen Shan appears to be similar to that of a fault propagation fold that has been strongly modified by faults (Fig. 7).

External structures of the Longmen Shan merge with those of the western Sichuan Basin. Folds in the Sichuan Basin are underlain by a décollement that continues to the west beneath the folds of the eastern Longmen Shan. This décollement must ramp down into the basement east of the Pengguan and Baoshan massifs (Fig. 5, sections B and C). Some thrust faults along the eastern front of the Longmen Shan may also root into the basement, but correlation of sedimentary strata across these thrust faults suggests small displacements.

Northwest of Chengdu, most of the Cenozoic shortening appears to be concentrated in the folded structure of the 
Pengguan massif. At this latitude, only one fold (the Longchuan anticline) is present in the Sichuan Basin, indicating only a few kilometers of displacement on the décollement beneath the basin. Here, Cenozoic folding along the eastern front of the Longmen Shan also does not require much shortening. North of the Longchuan anticline, the Mesozoic foredeep deposits are more uniformly inclined, dipping $15^{\circ}-20^{\circ} \mathrm{E}$ and flattening eastward to merge with strata in the Sichuan Basin. This suggests that a triangle zone (a type of blind thrust fault) may be present at depth beneath the range front.

South of the Pengguan massif, folding in the basin becomes more widely distributed; thrust faults also appear to the west within the Sichuan Basin and along the eastern flank of the Longmen Shan (Fig. 4), indicating increased displacement on the décollement. South of the Sichuan Basin, the structures are more complex and involve crystalline basement (Fig. 5, Section D).

A series of steeply dipping faults, some of which are active, parallel the Longmen Shan margin and cut or otherwise interact with the Cenozoic fold-and-thrust structure (Figs. 2, 4, and 6). The contact of Paleozoic and Mesozoic rocks with the Precambrian basement along the east side of the Pengguan massif is a steep-to-vertical fault or faults (profile A', Fig. 5). The same contact is depositional on the east side of the Baoshan massif and the northeast side of the Pengguan massif. To the north, these faults offset the thrusts of the Mesozoic thrust complex by $<1 \mathrm{~km}$, indicating little displacement on this steep fault system. The fault system continues northeast for $>100 \mathrm{~km}$ as the Beichuan fault, a likely candidate for rupture during the 12 May Wenchuan earthquake.

The west sides of the Baoshan and Pengguan massifs are truncated by steep, west-dipping normal faults that have a right-slip component and merge with the eastern boundary faults at the southern end of the Pengguan massif. The fault system is exposed almost directly above the epicenter of the Wenchuan earthquake as the Wenchuan-Maowen fault; however, this fault's location, sense of shear, and surface dip are not compatible with the focal mechanism for the initial rupture.

The magnitude of Cenozoic shortening across the Longmen Shan is variable but small, probably on the order of tens of kilometers. In eastern Tibet, few Cenozoic shortening structures are observed in the field, except in the Min Shan range to the north. The geometry of the Cenozoic shortening structures in the Longmen Shan is such that only some of the dip-slip displacement on deep faults may reach the surface, while the rest may be absorbed by folding within the overlying layers and in the Sichuan Basin.

\section{Sichuan Basin}

The Sichuan Basin is roughly circular, containing $>10 \mathrm{~km}$ of primarily Mesozoic and Paleozoic sedimentary rocks and rimmed along its southern margin by Cenozoic structures that merge westward and northward into the Longmen Shan. To the north and east, the surrounding ranges are folded belts of Late Triassic-Cretaceous and Late Cretaceous age, respectively. Thus, the basement beneath the basin remained relatively undeformed during the Mesozoic and Cenozoic deformations that affected the surrounding regions. Seismic tomography suggests that the basin is underlain by a lithosphere with higher than average $\mathrm{P}$ and $\mathrm{S}$ wave speeds at depths shallower than $250 \mathrm{~km}$, indicating a relatively strong cratonic root (Fig. 1).
Rocks exposed in the Sichuan Basin are mainly Cretaceous and, locally, Jurassic. Eocene rocks are folded and exposed in active anticlines that form ridges within the southwestern part of the basin and are unconformably overlain by Pleistocene conglomerate and sandstone (Fig. 4). Between folds, Eocene and Quaternary strata are generally subhorizontal. Quaternary strata are present only in the southwestern part of Sichuan Basin, southwest of the Longchuan anticline. These strata are typically $<100 \mathrm{~m}$ thick and are ponded behind the rising anticlines.

\section{South and East of the Longmen Shan}

To the south and east of the Longmen Shan, the eastern plateau wraps around the southern margin of the Sichuan Basin (Fig. 2). This area contains complexly superposed structures, including north-south- and northwest-southeast-trending Cenozoic folds and thrust faults. The faults and folds involve Precambrian basement, Paleozoic sedimentary strata, and Jurassic-Cretaceous foredeep deposits that correlate with rocks in the Longmen Shan and Sichuan Basin. These structures appear to be thin-skinned features above a shallow décollement within the basement. The westernmost folds and thrust faults continue from this region into the Longmen Shan, where they form the frontal structures along the range (Fig. 4).

\section{Min Shan and Huya Region}

The Min Shan, rising higher than $4000 \mathrm{~m}$, are bounded on the west by the Min Jiang fault zone and on the southeast by the Huya fault zone (Fig. 4). Both fault zones consist of steep, active, west-dipping reverse faults (Kirby et al., 2000). In 1879, a magnitude $~ 7-8$ earthquake occurred along the Min Jiang fault zone (Editorial Board, State Seismological Bureau, 1989) and in 1976, a magnitude 7.2 earthquake ruptured the Huya fault zone with dip-slip and left-slip components of displacement (Jones et al., 1984).

The western slope of the Min Shan is an erosion surface cut on older rocks. The surface is blanketed by west-dipping Quaternary deposits (Kirby et al., 2000), including a 7-km-wide basin filled with strata that dip $10^{\circ}-20^{\circ}$ west, indicating Quaternary tilting or folding.

The Min Jiang and Huya fault systems interact with the active, east-west-trending Xue Shan and Qingchuan faults, which relay deformation southward and eastward from the southern end of the Min Shan (Figs. 2 and 4). Faults in this area generally follow the boundary between the Xue Shan plateau (consisting of basement and a Paleozoic platform section) and Triassic flysch, suggesting that the fault geometry is controlled by a contrast in crustal strength between the two domains. The active faults of the northern Longmen Shan lie outboard of the Min Shan.

\section{TOPOGRAPHY}

The Longmen Shan and the Min Shan are asymmetric ranges bounded by steep, high-relief margins on their eastern sides and only modest western slopes. To the west, elevations rise toward $>5000 \mathrm{~m}$ on the Tibetan plateau. The steepest margin on the eastern Tibetan plateau occurs where the Longmen Shan border the Sichuan basin; elsewhere, the plateau margin is gently sloping. To the north, the crest of the Longmen Shan deviates westward from the range front and continues into the Min Shan (Figs. 2 and 3). Much of the active convergence along the east side of the plateau follows the high topography of these ranges. 
The modern high topography of the Longmen Shan and the eastern plateau was probably not established until the Late Cenozoic. Low-temperature isotopic dating indicates that relief along the Longmen Shan developed between 5 and $12 \mathrm{Ma}$ (Kirby et al., 2002), while initiation of rapid river incision into the eastern plateau appears to have begun between 8 and 15 Ma (Clark et al., 2005; Ouimet, 2007).

\section{ESTIMATES OF DEFORMATION BASED ON GPS MEASUREMENTS}

Elastic strain accumulation during interseismic intervals influences surface displacements measured by GPS; accurate interpretation of GPS data should account for this accumulation of elastic strain and, in complex regions like eastern Tibet, for three-dimensional (3-D) fault geometries and 3-D elastic structure. In this analysis of GPS data, we use the block modeling method of Meade and Hager (2005a), in which interseismic strain accumulation is assumed to be balanced eventually by elastic strain release on fault zones (Meade, 2007; Meade and Hager, 2005b; Meade et al., 2002; Molnar and Ghose, 2000). The results are independent of the GPS reference frame assumed; velocities shown here are relative to southern China.

The Meade (2007) block model for Tibet used the GPS velocity field of Zhang et al. (2004) and yielded $\sim 3 \mathrm{~mm} / \mathrm{yr}$ right-slip and $\sim 2 \mathrm{~mm} / \mathrm{yr}$ convergence along the Longmen Shan boundary. We use the more recent velocity field of Gan et al. (2007) combined with that of Shen et al. (2005) and an updated solution from the network of King et al. (1997) and Chen et al. (2000). We found it impossible to fit the updated GPS data adequately with the Meade (2007) block geometries; therefore, we modified the block geometry west of the Longmen Shan to be more consistent with geologic structures and regional GPS data. In particular, we divided the eastern part of Meade's East Tibetan Plateau Block into three small blocks (Fig. 2). The East Tibet-Songpan boundary coincides with a belt of $m_{b} \geq 4$ seismic events (Fig. 1), where Shen et al. (2005) previously pointed out a GPS velocity gradient. The Danba-Songpan boundary is also defined by seismicity and connects to the Longmen Shan boundary near the epicenter of the Wenchuan earthquake. The Songpan-Xue Shan boundary extends through the active Min Shan and Huya fault zones, connecting the Longmen Shan boundary to the Kun Lun fault.

With this block geometry, we fit the GPS data to within their uncertainties $(2-3 \mathrm{~mm} / \mathrm{yr}$ in two dimentions with $90 \%$ confidence) in the Sichuan Basin, Songpan, and Xue Shan blocks. Due to limited data and one anomalous site, we believe that results for the Danba block are not reliable. All blocks northwest of the Sichuan Basin show northwest translation plus clockwise rotation. The initial rupture site for the Wenchuan earthquake lies near the southwestern end of the Songpan-Sichuan Basin block boundary. On this boundary, we estimate a roughly uniform $1 \pm 1 \mathrm{~mm} / \mathrm{yr}$ right-slip. Assuming a $45^{\circ}$ west-dipping fault, we estimate $1 \pm 1 \mathrm{~mm} / \mathrm{yr}$ dipslip in the southwest, increasing to $3 \pm 1 \mathrm{~mm} / \mathrm{yr}$ in the northeast. The sense of slip given by the block model is consistent with available estimates of the focal mechanism for the Wenchuan earthquake, with dip-slip and right-slip components (Ji, 2008).
The Xue Shan-Sichuan Basin boundary has an estimated $1 \pm 1 \mathrm{~mm} / \mathrm{yr}$ right-slip and dip-slip displacement, increasing slightly from southeast to northwest. Ji's (2008) finite fault solution indicates that primarily right-lateral strike-slip motion occurred on this fault segment during the Wenchuan earthquake.

The Songpan-Xue Shan boundary along the Min Jiang fault system yields estimated dip-slip motion increasing from south $(2 \pm 1 \mathrm{~mm} / \mathrm{yr})$ to north $(3 \pm 1 \mathrm{~mm} / \mathrm{yr})$ on an assumed $45^{\circ}$ westdipping fault. Significant strike-slip occurs only along the jog in the boundary that corresponds to the right-slip Qingchuan fault. The Songpan-East Tibet boundary shows relatively uniform deformation along its length: $3 \pm 1 \mathrm{~mm} / \mathrm{yr}$ right-slip and $2 \pm 1 \mathrm{~mm} / \mathrm{yr}$ convergence.

\section{CRUSTAL COMPENSATION}

The development of the Longmen Shan appears closely linked to its proximity to the Sichuan Basin. The lack of significant Late Cenozoic subsidence in the Sichuan Basin indicates little flexural loading of Sichuan Basin lithosphere during Late Cenozoic thrust faulting and uplift of the Longmen Shan. Gravity data across the Longmen Shan also suggest that little flexural loading of the Sichuan Basin occurred in Late Cenozoic time, and the crust here is (nearly) Airy-compensated (Fig. 3; but see Jiang and Yu, 2005).

These observations suggest that (i) the Sichuan lithosphere may be broken, or its flexural strength nearly zero, beneath the eastern Longmen Shan; or (ii) loading of the Sichuan lithosphere occurred by emplacement of crust over, under, and/or into the flexurally strong portion of the Sichuan lithosphere such that the net vertical load on the Sichuan lithosphere is small (Fig. 7). In either case, mechanical coupling between loads represented by the high topographic edifice of the plateau and the foreland lithosphere is small and highly atypical of foreland fold-and-thrust belts. This observation is important and should be incorporated into analyses of Cenozoic deformation in the Longmen Shan.

\section{VARIATIONS IN ELASTIC AND RHEOLOGICAL STRUCTURE}

P-wave tomography reveals a seismically fast structure beneath the Sichuan Basin extending to $\sim 250 \mathrm{~km}$ depth (Li et al., 2006, 2008; Fig. 1), indicating that the basin is underlain by a deeply rooted, probably cold, craton-like lithosphere. Together with the observation that the Sichuan Basin largely escaped Mesozoic and Cenozoic deformations that affected the surrounding zones, this suggests that the Sichuan Basin lithosphere is mechanically strong compared to surrounding regions.

Above $\sim 250 \mathrm{~km}$ depth, the eastern plateau region is seismically slow, probably reflecting lower mechanical strength and elevated temperatures in the lithosphere (see Li et al., 2006, 2008). Alkali-rich magmatic rocks that were erupted in the eastern plateau from earliest Cenozoic to Pliocene time have melt temperatures in excess of $\sim 1300{ }^{\circ} \mathrm{C}$ at depths of $80-100 \mathrm{~km}$, indicating anomalously high temperatures at the base of, and probably throughout, the crust of the eastern plateau (Holbig and Grove, 2008). Magnetotelluric data from the eastern and south-central plateau also indicate a hot, fluid-rich middle crust (Nelson et al., 1996). Surface-wave tomography (Yao et al., 
2006, 2008) and receiver function analysis (Xu et al., 2007) from regional arrays in eastern Tibet show structures with low shear wave speed in the middle and lower crust.

Such large variations in rheologic structure have important effects on deformation at all time scales. Incorporating such variations in calculations of expected coseismic displacements for this earthquake produces results that differ by $20 \%$ in the near-field and by a factor of two in the far-field. Over geologic time, the crustal low-velocity zones may form an irregular, interconnected, network of channels in the middle and lower crust (Yao et al., 2006, 2008). Determining how these structures affect the postseismic deformation that will be observed in the next months to years will provide a unique opportunity to compare crustal rheologies on geodetic and geologic time scales.

\section{CRUSTAL THICKENING PROCESS}

The age of crustal thickening beneath the Longmen Shan and eastern plateau is probably similar to that of surface uplift, which is younger than $15 \mathrm{Ma}$. Based partially on the absence of significant Late Cenozoic shortening structures south of the Kun Lun fault, Clark and Royden (2000) proposed that crustal thickening in eastern Tibet occurred largely within a weak (low-viscosity) zone in the mid- to lower crust. A variety of data are consistent with this interpretation (e.g., high crustal temperatures, slow seismic wave speeds, flat to gently dipping topographic surfaces, etc.). If this interpretation is generally correct, the zone of weak crust probably does not extend beneath the eastern Longmen Shan, because crust with extensive zones of weakness at depth cannot support steep topographic gradients of significant lateral extent.

Clark and Royden (2000) also postulated that the edge of the high plateau may be narrowly localized along the Longmen Shan because the mechanically strong lithosphere of the Sichuan Basin obstructs eastward flow of weak crust at depth (also see Cook and Royden, 2008). In their conception, localization of Late Cenozoic deformation and active faulting along the Longmen Shan is largely controlled by the rheological contrast between the weaker crust of eastern Tibet and the cratonlike crust/lithosphere of the Sichuan Basin. They attributed the northeastward motion of east Tibetan crust, relative to the Sichuan Basin, as related to the growth of the eastern plateau to the northeast, with northeastward-moving crustal fragments within eastern Tibet diverted around the mechanically strong Sichuan Basin block (Fig. 1 inset and Fig. 2).

\section{ROLE OF LATE CENOZOIC FAULTING IN THE LONGMEN SHAN}

We propose that the primary function of Late Cenozoic structures in the Longmen Shan is to accommodate differential uplift across the eastern plateau margin and the northeastward movement of Tibetan crust relative to the Sichuan Basin. We also propose that the modified fault-propagation fold structure of the Longmen Shan is linked to ductile thickening within the deeper crust in a manner that is not completely clear. Figure 7 shows a simplified illustration of one possible geometry, in which upper-crustal layers of the Longmen Shan are folded upward above a ductilely thickening deeper crust. Competent rocks in the lower crust or upper mantle, if present, may also be flexed downward at the base of the enlarging crustal root, perhaps imparting a small flexural signal to the Moho (see gravity analysis of Jiang and Yu, 2005).

This interpretation is consistent with the predominance of Late Cenozoic high-angle reverse faults over gently dipping thrust faults in the Longmen Shan and Min Shan and with the slow rates of GPS-determined convergence. It is also consistent with the lack of Late Cenozoic foreland subsidence in the Sichuan Basin, because the geometry indicated in Figure 7 may produce little to no net loading (and could produce uplift) of the foreland region.

\section{SLIP RATE AND RECURRENCE INTERVAL}

Long-term rates of vertical uplift of $\sim 0.3-0.8 \mathrm{~mm} / \mathrm{yr}$ can be obtained by dividing the topographic relief across the Longmen Shan $(\sim 4 \mathrm{~km})$ by the estimated initiation age for surface uplift (ca. 5-12 Ma). Adding an estimated 5-8 km for denudation above the Pengguan and Baoshan massifs (Kirby et al., 2002) yields estimated rates of rock uplift of $\sim 0.7-1.2 \mathrm{~mm} / \mathrm{yr}$. The GPS-estimated rate of dip-slip, $1 \pm 1 \mathrm{~mm} / \mathrm{yr}$, near the epicenter of the Wenchuan earthquake, is assumed to occur on a $45^{\circ}$ west-dipping fault, giving convergence and differential uplift of $\sim 0.7 \pm 0.7 \mathrm{~mm} / \mathrm{yr}$. We suggest that the magnitude of Late Cenozoic shortening across the Longmen Shan may not be much larger than the magnitude of vertical rock uplift, perhaps as little as 10-20 km.

Approximate bounds on the average recurrence interval for earthquakes similar to the 12 May 2008 event are obtained by dividing the average coseismic slip of $\sim 5 \mathrm{~m}$ ( $\mathrm{Ji}, 2008$ ) by the GPS-determined dip-slip rate of $1 \pm 1 \mathrm{~mm} / \mathrm{yr}$, or by the estimated long-term uplift rate of $\sim 0.7-2.2 \mathrm{~mm} / \mathrm{yr}$. Both suggest an average recurrence interval in the general range of 2,000-10,000 yr.

GPS-determined slip rates across the Longmen Shan, and estimated recurrence intervals, are dependent in detail on the model assumptions used in analyzing the data. For the block model used here, deformation rates computed across the Longmen Shan are sensitive to the assumed number and location of blocks. The results are also sensitive to potential rheological inhomogeneities in the lithosphere. Undoubtedly, the results presented here will continue to be refined, especially because some of the block boundaries are marked by zones of diffuse seismicity without well-determined active faults. Ongoing study of coseismic and postseismic displacements related to the 12 May 2008 Wenchuan earthquake should provide much data to test the hypotheses presented in this paper.

\section{ACKNOWLEDGMENTS}

Our work in eastern Tibet has been supported by the National Science Foundation since 1991, most recently by grant EAR-0003571. We are particularly grateful to former director Liu and present director Ding of the Chengdu Institute of Geology and Mineral Resources for the support they have provided over the past 20 years. We also thank Ken Hudnut and an anonymous reviewer for speedy and helpful reviews, and David Fastovsky for editorial help, for arranging rapid publication of this article, and especially for his forbearance with numerous, rapidly evolving drafts. 


\section{REFERENCES CITED}

Burchfiel, B.C., Chen, Z., Liu, Y., and Royden, L.H., 1995, Tectonics of the Longmen Shan and adjacent regions: International Geology Review, v. 37, p. 661-738.

Chen, Z., Burchfiel, B.C., Liu, Y., King, R.W., Royden, L.H., Tang, W., Wang, E., Zhao, J., and Zhang, X., 2000, Global positioning system measurements from eastern Tibet and their implications for India/Eurasia intercontinental deformation: Journal of Geophysical Research, v. 105, p. 16,215-16,227.

Clark, M.K., and Royden, L.H., 2000, Topographic ooze: Building the eastern margin of Tibet by lower crustal flow: Geology, v. 28, p. 703-706, doi: 10.1130/00917613(2000)28<703:TOBTEM>2.0.CO;2.

Clark, M.K., House, M.A., Royden, L.H., Burchfiel, B.C., Whipple, K.X., Zhang, X., and Tang, W., 2005, Late Cenozoic uplift of southeastern Tibet: Geology, v. 33, p. 525-528, doi: 10.1130/G21265.1.

Cook, K.L., and Royden, L.H., 2008, The role of crustal strength variations in shaping orogenic plateaus, with application to Tibet: Journal of Geophysical Research, doi: 10.1029/2007JB005457.

Editorial Board, State Seismological Bureau, 1989, Lithospheric dynamics atlas of China: Beijing, China Cartographic Publishing House, p. 23.

Engdahl, E.R., van der Hilst, R.D., and Buland, R.P., 1998, Global teleseismic earthquake relocation from improved travel times and procedures for depth determination: Bulletin of the Seismological Society of America, v. 88, p. 722-743.

Gan, W., Zhang, P., Shen, Z.-K., Niu, Z., Wang, M., Wan, Y., Zhou, D., and Cheng, J., 2007, Present-day crustal motion within the Tibetan Plateau inferred from GPS measurements: Journal of Geophysical Research, v. 112, B08416, doi: 10.1029/2005JB004120.

Holbig, E.S., and Grove, T.L., 2008, Mantle melting beneath the Tibetan Plateau: Experimental constraints on ultra-potassic magmatism: Journal of Geophysical Research, v. 113, B04210, doi: 10.1029/2007JB005149.

Ji, C., 2008, Preliminary result of the May 12, $2008 M_{W} 7.9$ eastern Sichuan, China earthquake, May 12, 2008: http://www.geol.ucsb.edu/faculty/ji/big earthquakes/2008/05/12/ShiChuan.html (last accessed 8 June 2008).

liang, X., and Yu, J., 2005, Mapping the deep lithospheric structure beneath the eastern margin of the Tibetan Plateau from gravity anomalies: Journal of Geophysical Research, v. 110, B07407, doi: 10.1029/2004JB003394.

Jones, L.M., Han, W., Hauksson, E., Jin, A., Zhang, Y., and Luo, Z., 1984, Focal mechanisms of the Songpan earthquakes of August 1976 in Sichuan, China: Journal of Geophysical Research, v. 89, p. 7697-7707, doi: 10.1029/JB089iB09p07697.

King, R.W., Shen, F., Burchfiel, B.C., Royden, L.H., Wang, E., Chen, Z., Liu, Y., Zhang, X.-Y., Zhao, J.-X., and Li, Y., 1997, Geodetic measurement of crustal motion in southwest China: Geology, v. 25, p. 179-182, doi: 10.1130/0091-7613(1997) 025<0179:GMOCMI>2.3.CO;2

Kirby, E., Whipple, K.X., Burchfiel, B.C., Tang, W., Berger, G., Sun, Z., and Chen, Z., 2000, Neotectonics of the Min Shan, China: Implications for mechanisms driving Quaternary deformation along the eastern margin of the Tibetan Plateau: Geological Society of America Bulletin, v. 112, p. 375-393, doi: 10 1130/0016-7606(2000)112<0375:NOTMSC $>2.3 . C O ; 2$.

Kirby, E., Reiners, P.W., Krol, M.A., Whipple, K.X., Hodges, K.V., Farley, K.A., Tang, W., and Chen, Z., 2002, Late Cenozoic evolution of the eastern margin of the Tibetan Plateau: Inferences from ${ }^{40} \mathrm{Ar} /{ }^{39} \mathrm{Ar}$ and $(\mathrm{U}-\mathrm{Th}) / \mathrm{He}$ thermochronology: Tectonics, v. 21, 1001, doi: 10.1029/2000TC001246.

Li, C., van der Hilst, R.D., and Toksoz, M.N., 2006, Constraining spatial variation in P-wave velocity in the upper mantle beneath SE Asia: Physics of Earth and Planetary Interiors, v. 154, p. 180-195.

Li, C., van der Hilst, R.D., Engdahl, E.R., and Burdick, S., 2008, A new global mode for P-wave speed variations in Earth's mantle: Geochemistry Geophysics Geosystems, doi: 10.1029/2007GC001806.
Meade, B.J., 2007, Present-day kinematics at the India-Asia collision zone: Geology, v. 35, p. 81-84, doi: 10.1130/G22924A.1.

Meade, B.J., and Hager, B.H., 2005a, Block models of crustal motion in souther California constrained by GPS measurements: Journal of Geophysical Research v. 110, B03403, doi: 10.1029/2004JB003209.

Meade, B.J., and Hager, B.H., 2005b, Spatial localization of moment deficits in southern California: Journal of Geophysical Research, Solid Earth, v. 110, B04402, doi: 10.1029/2004JB003331.

Meade, B.J., Hager, B.H., McClusky, S.C., R.E., Reilinger, S., Ergintav, S., Lenk O., Barka, A., and Ozener, H., 2002, Estimates of seismic potential in the Marmara Sea region from block models of secular deformation constrained by global positioning system measurements: Bulletin of the Seismological Society of America, v. 92, p. 208-215, doi: 10.1785/0120000837.

Molnar, P. and Ghose, S., 2000, Seismic moments of major earthquakes and the rate of shortening across the Tien Shan: Geophysical Research Letters, v. 27 p. 2377-2380, doi: 10.1029/2000GL011637.

Nelson, K.D., Zhao, W., Brown, L.D., Kuo, J., Jinkai Che, J., Xianwen Liu, X., Klemperer, S.L., Makovsky, Y., Meissner, R., Mechie, J., Kind, R., Wenzel, F., Ni, J., Nabelek, J., Chen, L., Tan, H., Wei, W., Jones, A.G., Booker, J., Unsworth, M., Kidd, W.S.F., Hauck, M., Alsdorf, D., Ross, A., Cogan, M., Wu, C., Sandvol, E., and Edwards, M., 1996, Partially Molten Middle Crust Beneath Southern Tibet: Synthesis of Project INDEPTH Results: Science, v. 274 p. 1684-1688, doi: 10.1126/science.274.5293.1684.

Ouimet, W., 2007, Dissecting the eastern margin of the Tibetan Plateau: A study of landslides, erosion and river incision in a transient landscape [Ph.D. thesis] : Cambridge, Massachusetts Institute of Technology, $197 \mathrm{p}$.

Shen, Z.-K., Lü, J., Wang, M., and Burgmann, R., 2005, Contemporary crustal deformation around the southeast borderland of the Tibetan Plateau: Journal of Geophysical Research, v. 110, B11409, doi: 10.1029/2004JB003421.

U.S. Geological Survey, 2008, National Earthquake Information Center, 3 June 2008 http://earthquake.usgs.gov/eqcenter/eqinthenews/2008/us2008ryan/ (last accessed 8 June 2008).

Xu, L., Rondenay, S., and Van der Hilst, R.D., 2007, Structure of the crust beneath the southeastern Tibetan Plateau from teleseismic receiver functions: Physics of the Earth and Planetary Interiors, v. 165, p. 176-193.

Yao, H., van der Hilst, R.D., and de Hoop, M.V., 2006, Surface-wave array tomography in SE Tibet from ambient seismic noise and two-station analysis: I-Phase velocity maps: Geophysical Journal International, v. 166, p. 732-744, doi: 10.1111/j.1365-246X.2006.03028.x.

Yao, H., Beghein, C., and van der Hilst, R.D., 2008, Surface-wave array tomography in SE Tibet from ambient seismic noise and two-station analysis: II-Crustal and upper mantle structure: Geophysical Journal International, v. 173, p. 205-219, doi: 10.1111/j.1365-246X.2007.03696.x

Zhang, P., Shen, Z., Wang, M., Gan, W., Burgmann, R., Molnar, P., Wang, Q., Niu, Z., Sun, J., Wu, J., Sun, H., and You, X., 2004, Continuous deformation of the Tibetan Plateau from Global Positioning System data: Geology, v. 32 p. 809-812, doi: 10.1130/G20554.1.

Zhou, R., Li, Y., Densmore, A.L., Ellis, M.A., He, Y., Li, Y., and Li, X., 2007, Active tectonics of the Longmen Shan region of the eastern margin of the Tibetan plateau: Acta Geologica Sinica, v. 81, p. 593-604.

Manuscript received 4 June 2008; accepted 7 June 2008. *

\title{
GSATODAY
}

\section{IS OPEN ACCESS ONLINE}

\author{
Go to www.gsajournals.org and click on "Online Journals" then on the link \\ above the GSA Today cover. View back issues through the "Archives" button.
}

